Historic, Archive Document

Do not assume content reflects current scientific knowledge, policies, or practices. 



\section{KETURN TOPONOLOGY}

SEC DON OE IO OE ELATURE

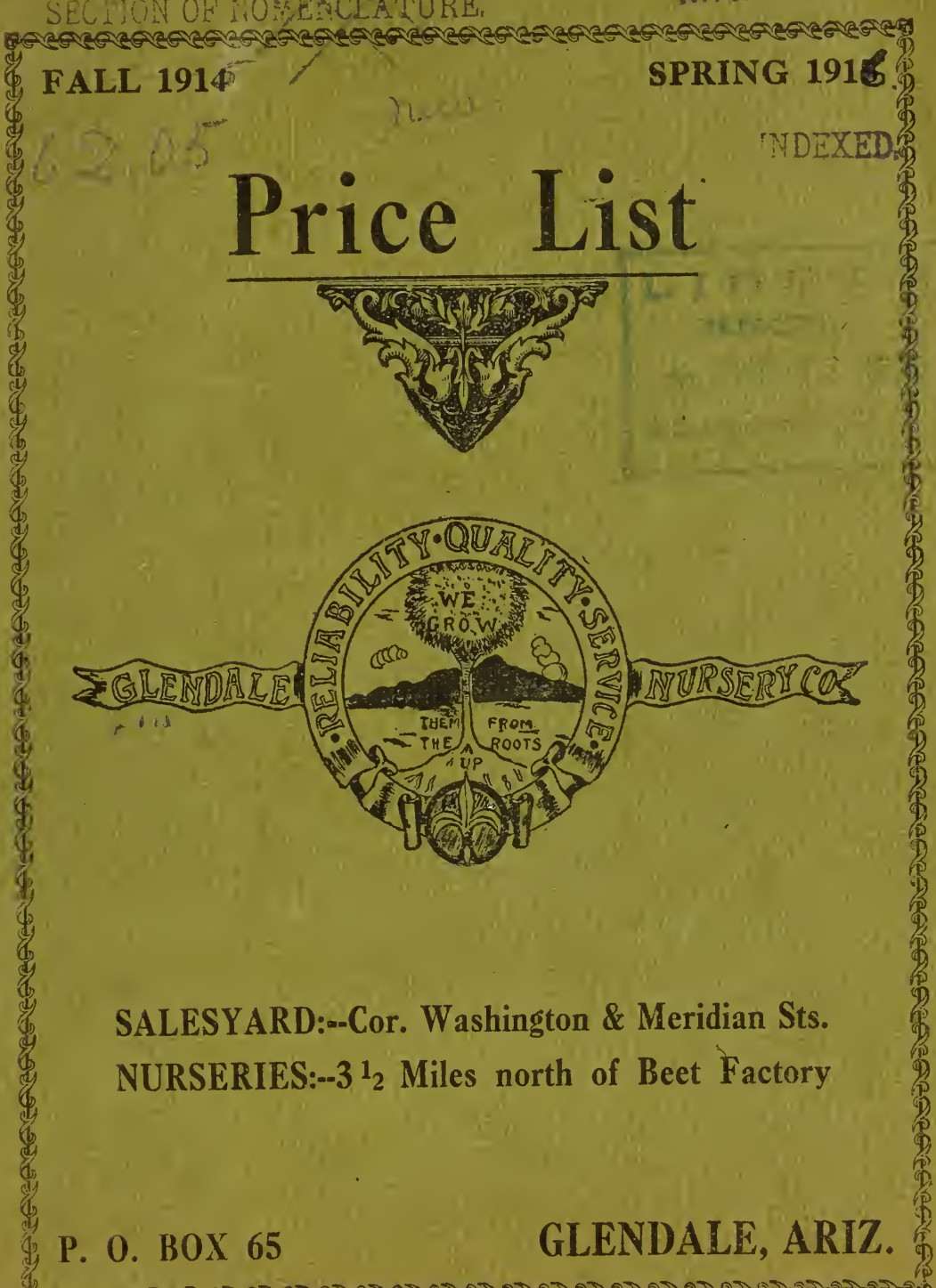
SPRING 1916. 
No. of Trees or Plants on an Acre

\begin{tabular}{|c|c|c|c|}
\hline $\begin{array}{l}\text { Distance } \\
\text { in Feet }\end{array}$ & $\begin{array}{l}\text { Number } \\
\text { of Plants. }\end{array}$ & $\begin{array}{l}\text { Distance } \\
\text { in Feet }\end{array}$ & $\begin{array}{l}\text { Number } \\
\text { of Plants. }\end{array}$ \\
\hline $4 \times 5$ & $. .2,178$ & $9 \times 12$ & ..... 403 \\
\hline $4 \times 6$ & 1,815 & $10 \times 10$ & 435 \\
\hline $4 \times 7$. & $\ldots 1,556$ & $10 \times 12$ & 363 \\
\hline $4 \times 8$ & $\ldots 1,361$ & $10 \times 15$ & 290 \\
\hline $5 \times 5$ & $\ldots 1,742$ & $10 \times 18$ & 242 \\
\hline $5 \times 6$ & $\ldots 1,542$ & $10 \times 20$ & 217 \\
\hline $5 \times 7$ & $\ldots 1,242$ & $12 \times 12$ & 302 \\
\hline $5 \times 8$ & $\ldots 1,089$ & $12 \times 15$ & 242 \\
\hline $5 \times 9$ & 968 & $12 \times 20$ & 181 \\
\hline $6 \times 6$ & $\ldots 1,210$ & $15 \times 15$ & .. 193 \\
\hline $6 \times 7$. & $\ldots 1,037$ & $15 \times 18$ & 161 \\
\hline $6 \times 8$ & .... 907 & $15 \times 20$ & 145 \\
\hline $6 \times 9$ & ... 806 & $18 \times 18$ & 134 \\
\hline $6 \times 10$ & .... 726 & $18 \times 20$ & 121 \\
\hline $7 \times 7$ & ... 888 & $18 \times 24$ & 100 \\
\hline $7 \times 8$ & ... 777 & $20 \times 20$ & 108 \\
\hline $7 \times 9$. & .... 691 & $20 \times 24$ & .. 90 \\
\hline $7 \times 10$ & 622 & $20 \times 30$ & 72 \\
\hline $8 \times 8$ & $\ldots 680$ & $24 \times 24$ & 76 \\
\hline $8 \times 9$. & 605 & $25 \times 25$ & 69 \\
\hline $8 \times 10$ & 544 & $30 \times 24$ & 60 \\
\hline $8 \times 11$ & .... 495 & $30 \times 30$ & 48 \\
\hline $8 \times 12$ & ... 453 & $30 \times 36$ & 40 \\
\hline $9 \times 9$ & ... 537 & $40 \times 40$ & 27 \\
\hline $9 \times 10$. & $\ldots .484$ & $50 \times 50$ & 17 \\
\hline $9 \times 11$. & ... 440 & $60 \times 60$ & $\ldots \ldots \ldots$ \\
\hline
\end{tabular}




\section{GLENDALE NURSERY CO.}

\section{OUR POLICY}

\section{INDEXED,}

We have specialized in growng ligunus, healthy trees for the planet, they are grown on the Glendale luses. It has been our study and life work of propagating the best trees adapted to our climate, which has done so much to make our business a success. The true nurseryman must be an experienced grower, a knowledge of orchard methods, varieties and markets is as necessary to good nursery work as the left hand is to the right.

Some claim to be nurserymen who know nothing about the growing -they are not nurserymen, they are dealers; they understand little about the young trees before they sell them, and care less after they leave their hands.

We grow our own trees from the roots up, we sow the finest of seed, and bud the seedlings from bearing trees, everything is kept true to name from the time the buds are put in, until they leave our packing shed, hence we know what we are giving our customers.

Our business is to grow the best trees that can be propagated and sell them direct to you from our nurseries at the lowest possible price. Our business is to give you accurate, careful information, so that you may select the best varieties of trees for your own special requirements, you want the healthiest, hardiest and most vigorous trees and plants at reasonable cost. We have and will deliver just what you want and the way you want it. Lets Trade.

\section{DIRECTIONS TO CUSTOMERS.}

(1.) It pays to order early and have your trees delivered as soon as the weather conditions will premit. We assure safe arrival.

(2.) We recommend early planting, from January 1st, to March 15 th, is the best time.

(3.) After receiving trees, cover the roots over with moist soil at once, until ready to plant.

(4.) Before planting, prune off all broken and long roots, peach, plum, apricot, etc., should be pruned back to about 18 inches from ground 


\section{GLENDALE NURSERY CO.}

(5.) Dig holes large enough to allow all roots without cramping Fill holes half full witl soil, put in a pail full of water to settle dirt around the roots, then fill up with top soil. The cause of trees failing to start 11 many instances is due to failure to settle the soil around the roots. Do not tramp the soil, let the water settle the soil

(6.) Every precaution is taken to have each tree and plant true to label. If from any fault of ours a tree is not true to label, we will on proper proof, replace the number.

We warrant all trees and plants to be good, strong and healthy, but having no control over planting or care after delivery to the buyer, we will not be responsible in any way than stated.

(7.) In cases where patrons are not aequanted with rarieties the selection may be left to us. When ordering please state whether sub stitution will be allowed, should we be out of any varieties or sizes called for. In the absence of instructions we usually feel at liberty to fill or ders with other simila! and if possible better varieties which we may have on hand at the time.

(8) Caution: Be careful in unpacking to note everything and either plant or cover up with moist soil at once

liet your order in early for delivery at the proper season.

\section{NOT LISTED.}

frees or plants not in this list can be had at market prices 50 trees at the 1001 rate: 500$)$ trees at the 1000 rate.

Address all intespondence to

\section{GLENDALE NURSERY CO.,}

JOE HORNE, Manager

Glendale, Ariz. 


\section{PEACH}

\begin{tabular}{|c|c|c|}
\hline 3 to 4 feet & $\begin{array}{c}\mathrm{Each} \\
25 \mathrm{c}\end{array}$ & $\begin{array}{c}\text { Per } 100 \\
\$ 20.00\end{array}$ \\
\hline to 6 feet & $30 c$ & 25.00 \\
\hline
\end{tabular}

\section{Freestone Verieties}

$\begin{array}{lll}\text { Alexander } & \text { Foster } & \text { Murr } \\ \text { Alton } & \text { Krummels Late } & \text { Salway } \\ \text { Bell of Georgia } & \text { Lo:ell } & \text { Sabachi Winter } \\ \text { Elberta } & \text { Late Crawford } & \text { Slapiy }\end{array}$

\section{Early Crawford May flower}

Cling Stone Varieties.

Heath Cling

Phillips Cling ruscan Cling

Henrietlat Clini:

Red Bird rling

\section{APRICOT}

$\begin{array}{llrr}3 \text { to } 4 \text { feet } & \text { Each } & \text { Per } 100 & \text { Per } 1000 \\ 4 \text { to } 6 \text { feet } & \$ 25.00 & 30 \mathrm{c} & \$ 200.00 \\ \text { Blenheim } & \text { Noorepark } & 30.00 & 250.00 \\ \text { Hemshirk } & \text { New Castle } & \text { Royal } & \\ \end{array}$

\section{NECTARINE}

Each

Per 100

Per 1000

4. to 5 feet $35 c$

Stanwich

New White

$\$ 30.00$

$\$ 250.00$

Red Roman

\section{PLUM}

$\begin{array}{lllr} & \text { Each } & \text { Per } 100 & \text { Per } 1000 \\ 4 \text { to } 5 \text { feet } & \text { Greengage } & \$ 30.00 & \$ 250.00 \\ \text { Burbank } & \text { Kelsey Japan } & \text { Prunis Sononii } \\ \text { Climax } & \text { Gonzalas } & \text { Rerl Jume } & \\ \text { 1)amson } & \text { Satslimal } & \end{array}$

Wickson 


\section{GLENDALE NURSERY CO.}

PRUNES.

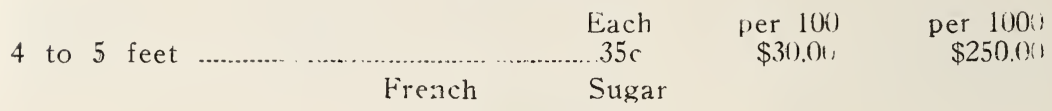

CHERRY.

4 to 5 feet $\quad \begin{array}{ccc}\text { Each } & \text { per } 100 & \text { per } 100 \\ \$ 250 & \$ 30.00 & 35 c\end{array}$ English Morella Early Richmond

PEAR

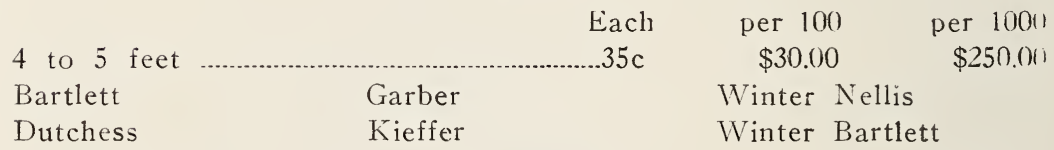

APPLE

Each per 100 per inon

4 to 5 feet $30 \mathrm{c}$

$\$ 25.00$

$\$ 20000$

Delicious

Red June

Bellefleur

Red Astrachan

W. W. Pearmain

Siberian Crab

Whitney Crab

\section{PERSIMMONS (Japane ${ }^{\mathrm{S}}$ )}

Each

per 100

per 1000

4 to 5 feet

$40 \mathrm{c}$

$\$ 35.00$

$\$ 3000$ 0

\section{QUINCE.}

Each

4 to 5 feet per 100

$\$ 30.00$ per 1000

$\$ 200.00$

Apple or Orange

FIG

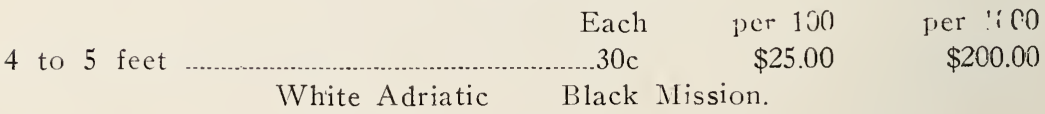

We carry all Varieties for the Northern Part of the State. Order Early. 


\section{ALMOND}

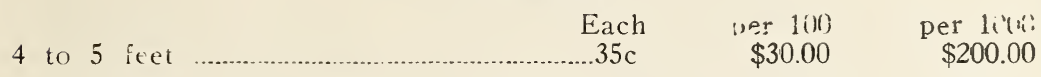
Ne Plus Ultra Jordan Nonpariel I. X. L. Texas Prolific.

\section{PECAN}

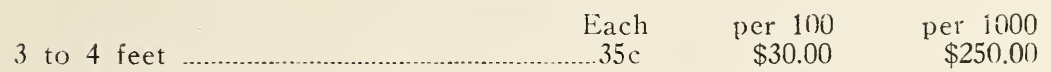

Paper Shell Seedlings, (from selected nuts)

Russell ( Budded) $75 \mathrm{c}$ each; $\$ 70$ per 100 Stuart (Budded) $75 \mathrm{c}$ each; $\$ 70$ per 100

\section{WALNUTS}

Secdlings, 4 to 6 feet, $50 c$ each.

Cirafted Varieties 31 , 4 feet, $\$ 150$ each; 4 to 6 feet, $\$ 1.75$ each.

\section{OLIVE.}
3 to 4 feet
Each
4 to 5 feet
$60 \mathrm{c}$
Per 100
$75 \mathrm{c}$
$\$ 55.00$
Per 1000
65.00
$\$ 500.00$
550.00

\section{Manzanillo Mission}

\section{GRAPES}
Black Hamburg
Each
$15 \mathrm{c}$
per 10
$\$ 1.00$
per 100
$\$ 5.00$
Concord
Muscat
Mission
Thompson's Seedless
Rosa Pern
Seedless Sultana
Emperor

\section{BLACKBERRIES.}

$10 \mathrm{c}$ each

60c per 10

$\$ 4.00$ per 100

\section{LOGANBERRY.}

$10 \mathrm{c}$ each

60 c per 10

$\$ 4.00$ per 100

\section{DEW BERRY}

$10 \mathrm{c}$ each

60 c per 10

$\$ 4.00$ per 100 


\section{STRAWBERRY}

20c dozen

Asparagus Roots, $\$ 3.00$ per 100 ,

Tomato plants, $10 \mathrm{c}$ doz., 50c per 100, \$4.00 per 1000 .

Cabbage plants 10 c doz. 50c per 100 .

Sweet Potatoe Plants, 50c per $100, \$ 5.00$ per 1000 . Order Early.

Always order as carly as possible and plant early too. Your trees and plants will have just that much more time to become firmly established in their new home before the hot weather arrives.

\section{AVOCADO}

\section{(Alligator Pear)}

Seedlings, 3 to 4 feet, $\$ 1.00$ each.

Budded varicties, $\$ 5.00$ each.

\section{GUAVAS}

Strawbery (inava, 50 c each.

\section{LOQUAT}

Aiance: 2 to, 3 feet, $\$ 2.00$ each.

Serdlings: 2 to 3 feet, 75 e each.

\section{FEIJOA}

3 feet, $\$ 1.00$

ORANGE.

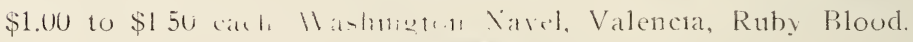

\section{LEMUN}

$\$ 1.00$ to $\$ 1.50$ each. Eureka, Lisbon.

\section{GRAPE FRUIT.}

$\$ 1.00$ to $\$ 1.50$ each. Narsh Seedless.

Prices on large quantities of Citrus fruit trees furnished on application. 


\section{GLENDALE NURSERY CO.}

\section{GLENDALE ROSES.}

Our roses are large field grown plants, buy direct and have them fresh from the ground.

Our roses are grown on their own roots and are better for the family garden than budded roses, they never sucker and produce wild roses, they have been blooming profusely this seascn.

\section{Rose Classification.}

T.-Tea: Of free blooming habit; delicate tea fragrance.

H. P.-Hybrid Perpetual: Of strong upright growth, flowers large and fragrant, very hardy.

H. T.-Hybrid Tea: A hardy everblooming rose, sweetscented

C.-Climbing roses.

P.-Polyantha or rambler.

$\begin{array}{cccr}\text { Each } & \text { Per doz } & \text { Per } 50 & \text { Per } 100 \\ 30 \mathrm{c} & \$ 3.00 & \$ 11.00 & \$ 20.00\end{array}$

American Beauty, H. P. Deep rose Glendale Beauty, H T. Rich yelBride, T. White

Bridesmaid, T. Clear pink

Cecile Brumner, P. Rosy pink

Crimson Rambler, P Crimson

Climbing Bride, C. T. White

Climbing Kaiserin, C. H. T. Ivory white

Climbing Wooten, C. H. T. Velvet Crimson

Caroline Testout, H. T. Bright Rose

Climbing Meteor, C. H. T. Red

Etoile de France, H. T. Rich Velvety crimson

Frau Karl Druschki, H. P. Snow white low

Gen. McArthur, H. T. Crimson

Gen. Jack, H. P. Crimson

Kaiserin, H. T. Ivory white

La France, H. T. Silvery pink

Mamon Cochet, T Ricli pink

Marschal Neil, C. T. golden yellow

Marie Van Houtte, T. White. shaded yellow and rose

Mrs. J. Laing, H. P. Deep rose

Perle des Jardin, H. P. Straw yellow

Paul Neyron, H. P. Deep rose

Saprono, T. Apricn yellow

Ulrich Brunner. H. P. Red

White Naman Cochet, T. Pure white

Roses not listed can be had at the same prices as the above. This is the best collection of roses and the only varieties we grow, wher va ricties we buy from Californa.

CARNATIONS-Colors: white, pink and red; 10, each. \$1.00 per doz.

CANNAS-Colors; yellow, white, red and crimson; 15 c each $\$ 1.0()$ jer 10 . 


\section{GLENDALE NURSERY CO.}

CHRYSANTHEMUMS-Colors; white, lavender, bronze and yellow; 10 c each, $\$ 1.00$ per doz. 10.

GERANIUMS-Colors; white scarlet and pink; $15 \mathrm{c}$ each, $\$ 1.00$ ) per

VIOLETS-35c per doz; $\$ 3.00$ per 10 )

\section{FERNS}

Asparagus Plumosus, 75c each in pots.

Asparagus Sprangerii, 75c each in put.

\section{VINES.}

Ampelopsis Veitch (Boston Ivy) 35c each. Clematis, 50c each Honey suckle, 25c each. English lvey, 30c each.

\section{UiMBRELLA (Texas) Each}

4 to 6 feet, $30 \mathrm{c} ; 6$ feet, $40 \mathrm{c} ; 8$ feet, $50 \mathrm{c}-$ whips

6 feet, 50c; 8 feet, $75 \mathrm{c}, \$ 1.00, \$ 1.50$-brancher.

\section{$\mathrm{ASH}$}

3 to 4 feet $25 c ; 4$ to 6 feet, 35c; 6 to 8 feet 5 (f) each Special prices on large quantities of ash and umbrella.

MULBERRY -4 to 6 feet, 35c each

BALM OF GILEAD -4 to 6 feet, $50 \mathrm{c}$ each.

WEEPING MULBERRY- $\$ 1.50$ each.

ACACIA-3 to 4 feet, 50c each.

CASUARINA (She Oak) -3 to 4 feet $50 \mathrm{c}$ each.

EUCALYPTIS-Rudis, Rostrata, Tereticornis, 3 to 4 feet, $35 \mathrm{c} ; 4$ to 6 feet $50 \mathrm{c}$ each

MYRTLE-25c + ach.

PEPPER-35c to $50 \mathrm{c}$ each.

CYPRESS-40 to $50 \mathrm{c}$ each.

STERICULA (Bottle Tree) 50c each

ARBORVITAE- $\$ 1.00$ to $\$ 1.50$ each.

PALMS-Fan, 50c each.

CALIFORNIA PRIVET-25c each; $\$ 20.00$ per 100 .

ENONYMUS JAPONICA-50c to $75 c$ each 


\section{Proper Distances Between Trees and Plants}

Peach, Plum and Apricot Trees ........................18 to 22 feet Orange and Grape Fruit........................................20 to 30 feet Almonds 20 to 25 feet

Pears and Apples .18 to 20 feet Olives 25 to 30 feet Grape Vines .6 to 8 feet Berries 4 to 6 feet

\section{Best Time to Plant}

Deciduous Fruit Trees .............................. Jan. to March Deciduous Shade Trees ................................Jan. to March Deciduous Shrubs .............................................Jan. to March Evergreen Trees ............................................Jan. to May 1st Evergreen shrubs ...........................................Jan. to May 1st Citrus Trees Feb. to May 1st Olive Trees Feb. to April Berry Plants Jan. to March Rose Bushes Jan. and Feb. Palms Jan. to May 1st 
